Egyptian Poultry Science Journal

http://www.epsaegypt.com

ISSN: 1110-5623 (Print) - 2090-0570 (On line)

\title{
EFFECT OF GRAPE SEED EXTRACT ON SOME PHYSIOLOGICAL CHANGES IN BROILERS UNDER HEAT STRESS
}

\author{
S. Z. El-Damrawy \\ Anim. Prod. Dep., Facul. of Agric., Tanta Univ., Egypt.
}

Accepted: 09/03/2014

\begin{abstract}
The major target of this study was to investigate the physiological changes in broiler chicks during exposure to high ambient temperature and elucidate the protective role of grape seed extract in alleviating these expected changes. One hundred and eighty Hubbard broiler chicks (1d-old) were used in the present work. The brooding temperature was maintained at $34^{\circ} \mathrm{C}(55 \% \mathrm{RH})$ for the first 2 days, and then decreased gradually to $24^{\circ} \mathrm{C}(55 \% \mathrm{RH})$ until 21 days of age. At day 22, birds were randomly divided into 4 groups with 3 replicates ( $n=15$ in each replicate). Birds in group1 (TN) kept at $24 \pm 1 \mathrm{C}$ and $55 \pm 5 \%$ $\mathrm{RH}$ and fed on commercial diet as a negative control. Birds in groups 2, 3 and 4 subjected to cyclic heat stress by exposing them to $36 \pm 1 \mathrm{C}$ and $65 \pm 5 \% \mathrm{RH}$ for $8 \mathrm{~h}$ (from 10 am to 6 $\mathrm{pm}$ ) during the period between $22 \mathrm{~d}$ to $40 \mathrm{~d}$ of age. Birds in group 2 (HSGSE0) fed on commercial diet without grape seed extract supplementation as a positive control. Birds in groups 3 (HSGSE1) and 4 (HSGSE2) fed on commercial diets supplemented with 100 and $200 \mathrm{mg} / \mathrm{kg}$ grape seed extract, respectively. Results showed that heat stress significantly increased body temperature (BT), respiratory rate (RR), heterophil/lymphocyte (H/L) ratio, corticosterone (CTC), triglycerides (TG), low density lipoprotein (LDL), high density lipoprotein (HDL) and liver malondialdehyde (MDA) and decreased liver superoxide dismutase (SOD) and glutathione (GSH) compared to TN group. Although BT and RR were not affected by GSE supplementation ( 100 or $200 \mathrm{mg} / \mathrm{kg}$ GSE), liver SOD and GSH were significantly increased and H:L ratio, CTC, TG, LDL, HDL and liver MDA were significantly decreased by GSE supplementation compared to GSE0 group. In conclusion, the obtained data demonstrate that grape seed extract could relieved some negative effects (stress indicators, lipid parameters and antioxidant enzymes) of broilers under heat stress. However, $200 \mathrm{mg} / \mathrm{kg}$ was more effective than $100 \mathrm{mg} / \mathrm{kg}$.
\end{abstract}

Key Words: Heat stress, grape seed, antioxidant, lipid peroxidation, broilers.

Corresponding author: saadzm@yahoo.com 


\section{INTRODUCTION}

High ambient temperature is one of the environmental factors influencing physiological traits and production of poultry (Azad et al., 2010). Ambient temperature over $32{ }^{\circ} \mathrm{C}$ causes heat stress in broilers (Cooper and Washburn 1998), which induces behavioral and physiological responses reflected by immunosuppression, high mortality rate and slight growth (Mujahid et al. 2005). Heat stress induces oxidative stress that result in increased reactive oxygen species production (Halliwell and Gutteridge, 1989). Excess levels of reactive oxygen species, reflected by the disturbance of balance between the oxidation and antioxidant defense systems, inducing lipid peroxidation, oxidative damages to biological molecules (Ando et al., 1997) and impaired muscle membrane integrity in breast muscle of broiler chickens (Sandercock, 2001). Oxidative stress as a result to heat stress exhibited more than a two fold increase of malondialdehyde as an indicator for lipid peroxidation, in the skeletal muscle (Mujahid et al., 2009 and Wang et al., 2009) and decreased serum vitamin and mineral concentrations which play an important role in the antioxidant defense system (Sahin et al., 2002, 2009). Lipid peroxidation can be minimized by supplementation of antioxidant vitamins (Puthpongsiriporn et al., 2001 and Franchini et al., 2002) or natural substances that possess antioxidant potential (Sahin et al., 2008 and Tuzcu et al., 2008). Antioxidants play an important role in protecting cells from reactive oxygen species by reducing free radicals and preventing the peroxidation of lipids (Grashorn, 2007 and Nanari et al., 2004).

Moreover, Benzie, 2003 reported that, antioxidant enzymes have the capacity to break down free-radical reactions using a chain reaction mechanism. The living organism can synthesize some of these antioxidants, whereas others need to be provided by the diet (Strain and Benzie, 1999). Recent studies have showed the importance of plant materials by-products that are particularly rich in polyphenols and have a wide range of biological activities. The inclusion of grape flavonoids causes a diminution of tissue lipid peroxidation in kidney, liver, and lung of rats (Preuss et al., 2001 and Rodrigo et al., 2005). Yilmaz and Toledo, 2004, reported that flavonoids have the capacity to act as powerful antioxidants by scavenging free radicals and terminating oxidative reactions. Murray (1995) recorded that grape seed extract contains the most beneficial groups of plant flavonoids, proanthocyanidins oligomers. It contains large quantities of monomeric phenolic compounds such as (+)-catechins, (-)-epicathechin and (-)-epicatechin-3-Ogallate, and dimeric, trimeric, and tetrameric proanthocyanidins (Saito et al., 1998). Recent investigations showed that grape seed extract decreased the incidence of free radical-induced lipid peroxidation and enhanced the antioxidant status in aged rats (Balu et al., 2005). It increases antioxidant capacity in chicken and turkey meat (Mitsumoto et al., 2005 and Mielnick et al., 2006). Grape seed extract contain 92 to $95 \%$ proanthocyanidins oligomers (Murray,1995). The activity of proanthocyanidins oligomers is approximately fifty times greater than that of vitamin $\mathrm{C}$ and vitamin $\mathrm{E}$, in terms of antioxidant action (Shi et al. 2003). proanthocyanidins might trap reactive oxygen species in plasma and interstitial fluid of the arterial wall, thereby inhibit the oxidation of LDL and show an antiatherosclerotic activity (Yamakoshi et al., 1999). Proanthocyanidins are potent antioxidants and exert many healthpromoting effects (Singh et al. 2004). Grape seed proanthocyanidins extract has been shown to have a cholesterol-lowering effect anticancer effect as well as antibacterial, antiviral, and antifungal 
activities (Shimada et al., 1999; Yamakoshi et al., 1999; Cos et al., 2003). Masaru et al. (2004) suggest that Grape seed proanthocyanidins extract can increase bone quality and bone strength of rat mandibles in the growth period.

Knowledge about the effect of grape seed polyphenols on lipid peroxidation and antioxidant status in heat-stressed broilers are limited. Therefore, the main goal of this study was to investigate the effect of grape seed extract on respiratory rate, body temperature, heterophil/lymphocyte ratio, corticosterone level, lipid perxidation and some antioxidant activities of broilers maintained at high ambient temperature.

\section{Materials and Methods}

\section{Birds and experimental design:}

One hundred eighty 1-d-old broiler chickens (Hubbard) were obtained from a local hatchery and reared in an environmentally controlled room. The brooding temperature was maintained at $34^{\circ} \mathrm{C}(55 \% \mathrm{RH})$ for the first 2 days, and then decreased gradually to $24^{\circ} \mathrm{C}(55 \%$ $\mathrm{RH})$ until 21 days of age. The chicks were kept in floor pens with fresh wood shaving. The birds received a commercial starter diet (21\% CP and $3000 \mathrm{kcal} \mathrm{ME} / \mathrm{kg}$.) until 21 days of age, after which a commercial grower diet (19\% CP and $3100 \mathrm{kcal} \mathrm{ME} /$ $\mathrm{kg}$.) was provided until the end of the experiment. Birds had ad-libitum feed and water throughout the experimental period. Birds were raised with continuous lighting. At day 22, birds were randomly divided into 4 groups with 3 replicates $(n=15$ in each replicate). Birds in group1 (TN) kept at $24 \pm 1 \mathrm{C}$ and $55 \pm 5 \% \mathrm{RH}$ and fed on commercial diet as a negative control. Birds in groups 2, 3 and 4 subjected to cyclic heat stress by exposing them to $36 \pm 1 \mathrm{C}$ and $65 \pm 5 \% \mathrm{RH}$ for $8 \mathrm{~h}$ (from 10 am to $6 \mathrm{pm}$ ) during the period between $22 \mathrm{~d}$ to 40d of age. Birds in group 2 (HSGSE0) fed on commercial diet without grape seed extract supplementation as a positive control. Birds in groups 3 (HSGSE1) and 4 (HSGSE2) fed on commercial diets supplemented with 100 and $200 \mathrm{mg} / \mathrm{kg}$ grape seed extract, respectively.

\section{Preparation of grape seed extract.}

Grape fruits were purchased from local market. Seeds were removed from the grapes, air dried in shade for one week and milled to obtain fine powder. The seeds powder was macerated in $75 \%$ ethanol for $72 \mathrm{hr}$ at room temperature. The ethanolic extract was evaporated (Rotary Evaporator) to eliminate ethanol and obtain GSE as a lyophilized powder (yield 25-30\%) according to Sarkaki et al. (2013).

\section{Blood and liver samples:}

At 40 days of age, Blood samples were collected into heparinized test tubes and kept on ice. Plasma was obtained after centrifugation at $3500 \mathrm{rpm}$ for $15 \mathrm{~min}$ then stored at $-20{ }^{\circ} \mathrm{C}$ for further analysis. Nine birds per treatment group ( 3 chickens per replication) were killed by decapitation. Liver was removed, chopped into small pieces, immediately frozen in liquid nitrogen and stored at $-80{ }^{\circ} \mathrm{C}$ until analysis. The homogenate of liver was prepared for the assays of superoxide dismutase (SOD), glutathione (GSH), and malondialdehyde (MDA).

\section{Measurements:}

Body temperature (BT) and respiratory rate $(\mathrm{RR})$ of the broilers were determined using the method described by Boulahson et al. (1995). Body temperature (BT) was monitored using a thermo-code electric gauge. The respiration rate (RR) was measured by counting the breaths/min by observing abdominal movement for one minute. The account and differential of white blood cells were determined according to the procedure outlined by Schalm et al. (1975). The heterophil/lymphocyte ratio was calculated. Plasma samples were subjected to biochemical analysis using commercial 
diagnostic kits. Plasma was submitted for determination of corticosterone (CTC), triglycerides (TG), low density lipoprotein (LDL) and high density lipoprotein (HDL). Malondialdehyde (MDA) was measured by the method described by Ohkawa et al. (1979). Superoxide dismutase (SOD) activity was measured based on ability of SOD to inhibit the reduction of nitroblue tetrazolum superoxide (Worthington, 1993). One unit of SOD is defined as the amount of sample resulting in $50 \%$ inhibition of nitroblue tetrazolum reduction. The glutathione (GSH) concentration was measured by the methods of Simons and Johnson (1978).

\section{Statistical analysis:}

The general linear models procedure of the SAS (1988) was used. Significant differences among means were determined by Duncan's multiple- range tests (Duncan, 1955).

\section{RESULTS}

\section{BT, RR, H:L ratio and CTC:}

Data of body temperature, respiratory rate, heterophil/lymphocyte ratio and corticosterone as affected by grape seed extract supplementation under high ambient temperature are presented in Table (1). Birds kept under high ambient temperature had greater BT, RR, H:L ratio and CTC than those of reared under TN conditions. Pretreatment of HS-treated birds with grape seed extract caused partial recovery of H:L ratio and CTC. Under heat stress, birds which received 100 and 200 GSE had lower CTC by $25.35 \%$ and $43.87 \%$, respectively, compared to GSE0 group. H:L ratio decreased significantly with birds received 100 GSE and 200 GSE by $18.46 \%$ and $38.46 \%$, respectively compared to GSE0 birds. Body temperature and respiratory rate were not significantly affected by GSE supplementation.

\section{Plasma Lipid parameters:}

Table (2) summaries The effect of heat stress and grape seed extract supplementation on TG, LDL and HDL values of broilers. Heat stress treatment without any supplementations leads to $45.10 \%, 63.08 \%$ and $27.38 \%$ increase in levels of TG, LDL and HDL, respectively as compared with control group. The level of 100 and 200 GSE supplementation had a significant and dynamic impact on plasma lipid parameters in broilers. Under heat stress conditions, plasma TG, LDL and HDL decreased significantly in birds received 100 and 200 GSE by $(7.69 \%$ and $31.41 \%),(21.70 \%$ and $36.44 \%)$ and $(3.17 \%$ and $19.87 \%$ ), respectively, compared to the GSE0.

\section{Liver lipid peroxidation and antioxidant indicators:}

Lipid peroxidation and antioxidant indicators activities of birds as influenced by heat stress and grape seed extract supplementation are illustrated in Table (3). Exposure to heat stress without any supplementation resulted in increase of MDA by $92.65 \%$ and reduction in the values of SOD and GSH by $30.23 \%$ and $34.01 \%$, respectively, as compared with control group. However, pretreatment of HS-treated birds with 100 and 200 grape seed extract resulted in the recovery of MDA by $18.07 \%$ and $41.22 \%$, respectively, and increased SOD by $22.84 \%$ and $26.21 \%$, respectively, as compared with GSE0 ones. The same trend was noticed with GSH (19.75\% and $46.61 \%$, respectively).

\section{DISCUSSION}

This study was carried out to investigate the physiological response of broiler chickens to cyclic heat stress and elucidate the possible protective effects of grape seed extract in alleviating the changes in lipid peroxidation and antioxidant indicators in plasma and liver of broilers. Heat stress significantly increased values of $B T, R R, H: L$ ratio and 
CTR compared to birds maintained at normal ambient temperature. These results are in agreement with those reported by Lin et al. (2006), Al-Ghamdi (2008) and Attia et al. (2010). They found that there was a significant increase in body temperature and respiration rate due to heat stress. Also, Sandercock et al. (2001) observed that exposure to high ambient temperature, elevated the body temperature. They suggested that, birds try to reduce body temperature by increasing their respiratory rate or panting. Star et al. (2008) and Willemsen et al. (2011) reported that there was a significant increase in corticosterone level due to heat stress, indicating that the chickens were stressed. Heterophil/lymphocyte ratio has been used as a reliable indicator of stress in birds (Gross and Siegel 1983). Moreover, McFarlane and Curtis (1989) and Yalcin et al. (2003) reported that heat exposure increased $\mathrm{H} / \mathrm{L}$ ratio in broiler chicks, indicating that the birds from the HS group were significantly stressed compared with control birds. Our results showed that, heterophil/lymphocyte ratio and corticosterone level of birds which maintained in the environmental temperature at $36+1 \mathrm{C}$ and received grape seed extract at 100 and $200 \mathrm{mg} / \mathrm{kg}$ diet were lower than the H/L ratio and CTC level of ones which did not receive grape seed extract in their diet. This indicates that grape seed extract supplementation could reduce the effect of heat stress in broilers. These results are in agree with Aengwanich and suttajit (2010) who reported that 300 and $400 \mathrm{mg} / \mathrm{kg}$ of polyphenols could reduce the effect of heat stress in broilers that maintained in the environmental temperature at $38+2 \mathrm{C}$. In our study, BT and $\mathrm{RR}$ of heat-stressed birds which received grape seed extract on their diet at 0,100 and $200 \mathrm{mg} / \mathrm{kg}$ did not differ. These data showed that grape seed extract had no effect on the body temperature or respiratory rate of broilers under heat stress. These results are in accordance with
Aengwanich and Suttajit (2010) who reported that polyphenols had no effect on the BT or RR of broilers under heat stress.

Oxidation of LDL is one of the primary mechanisms of lipid abnormalities such as hypertriglyceridemia (Devaraj and Jialal 2000), and hypercholesterolemia (Chen et al. 1997; Nassir et al. 1997) in stressed conditions. Our results showed that exposure to high ambient temperature significantly increased TG, LDL and HDL. Dietary supplementation of grape seed extract significantly decreased TG, LDL and HDL. These results are in harmony with Attia et al. (2010) who noted that chronic heat stress significantly increased plasma triglycerides. Also, Teissedre and Waterhouse (2000) noted a high correlation between the total phenol content and lowdensity lipoprotein oxidation in human. Furthermore, Akbari and Torki (2013) suggested that the high concentration of antioxidants might decrease lipid peroxidation and therefore reduce the serum concentration of triglycerides.

Our data of lipid peroxidation and antioxidant enzymes of liver showed that exposure to high ambient temperature significantly increased liver MDA and decreased SOD and GSH activities. In this regard, Mujahid et al. (2007) and Tan et al. (2010) indicated that high ambient temperature causes oxidative stress and tissue damage via lipid peroxidation. Furthermore, Sahin et al. (2010) observed that exposure to heat stress increased hepatic MDA level and decreased hepatic SOD and GSH-Px activities. The antioxidant power of polyphenols (i.e., proanthocyanidins, catechins, epicatechin, and procyanidin) found in grape seeds is reported to be 20 times greater than vitamin $\mathrm{E}$ and 50 times greater than vitamin $\mathrm{C}$ (Shi et al., 2003). In this study, dietary supplementation of grape seed extract significantly decreased MDA and increased SOD and GSH activities. Similar result was obtained by Sahin et al. (2010) who found that, in response to increasing supplemental 
green tea polyphenol level, there were linear decreases in hepatic MDA level and linear increases in hepatic SOD and GSHPx activities. Moreover, Aengwanich and Suttajit (2010) found the same result when they used polyphenol extracted from tamarind seed coat.

In conclusion, it could be recommended that exposure to high ambient temperature significantly increased body temperature, respiratory rate, stress indicators, lipid level, lipid peroxidation and decreased antioxidant indicators in liver of broilers. Although the two levels of Grape seed extract used in this study had no impact on body temperature or respiratory rate of the chicks, grape seed extract supplementation partially relieved the negative effects of heat stress on stress indicators, lipids profile, lipids peroxidation and activity of some antioxidant enzymes in broilers. Dietary supplementation of $200 \mathrm{mg} / \mathrm{kg}$ proofed to be more effective than $100 \mathrm{mg} / \mathrm{kg}$ in this regard.

Table (1): Effect of heat stress and grape seed extract supplementation on body temperature $(\mathrm{BT})$, respiratory rate $(\mathrm{RR}), \mathrm{H}: \mathrm{L}$ ratio and plasma corticosterone (CTC) level.

\begin{tabular}{|l|l|l|l|l|l|l|}
\hline & \multicolumn{1}{|c|}{ TN } & \multicolumn{1}{|c|}{$\begin{array}{c}\text { HSGSE } \\
\text { 0 }\end{array}$} & $\begin{array}{c}\text { HSGSE } \\
\mathbf{1}\end{array}$ & \multicolumn{1}{|c|}{$\begin{array}{c}\text { HSGSE } \\
\mathbf{2}\end{array}$} & SEM & Significant \\
\hline BT, ${ }^{\circ} \mathrm{C}$ & $40.32^{\mathrm{b}}$ & $42.35^{\mathrm{a}}$ & $42.28^{\mathrm{a}}$ & $42.15^{\mathrm{a}}$ & 0.21 & $*$ \\
$\mathrm{RR}$, breath/min & $50^{\mathrm{b}}$ & $122^{\mathrm{a}}$ & $118^{\mathrm{a}}$ & $115^{\mathrm{a}}$ & 3.95 & $* * *$ \\
$\mathrm{H}: \mathrm{L}$ ratio & $0.38^{\mathrm{c}}$ & $0.65^{\mathrm{a}}$ & $0.53^{\mathrm{b}}$ & $0.40^{\mathrm{c}}$ & 0.02 & $* *$ \\
$\mathrm{CTC}, \mathrm{ng} / \mathrm{ml}$ & $12.01^{\mathrm{c}}$ & $28.13^{\mathrm{a}}$ & $21.00^{\mathrm{b}}$ & $15.79^{\mathrm{c}}$ & 2.44 & $* *$ \\
\hline
\end{tabular}

Means within row for each item having different superscript differ significantly $*(\mathrm{p} \leq .05), * *(\mathrm{p} \leq .01), * * *(\mathrm{p} \leq .001)$

Table (2): Effect of heat stress and grape seed extract supplementation on plasma lipids profile.

\begin{tabular}{|l|l|l|l|l|l|l|}
\hline & TN & $\begin{array}{c}\text { HSGSE } \\
\mathbf{0}\end{array}$ & $\begin{array}{c}\text { HSGSE } \\
\mathbf{1}\end{array}$ & \multicolumn{1}{|c|}{ HSGSE2 } & SEM & Significant \\
\hline TG (mg/dl) & $104.11^{\mathrm{c}}$ & $151.06^{\mathrm{a}}$ & $139.45^{\mathrm{b}}$ & $103.62^{\mathrm{c}}$ & 4.79 & $* * *$ \\
LDL (mg/dl) & $38.79^{\mathrm{c}}$ & $63.26^{\mathrm{a}}$ & $49.53^{\mathrm{b}}$ & $40.21^{\mathrm{c}}$ & 3.55 & $* * *$ \\
HDL (mg/dl) & $25.49^{\mathrm{b}}$ & $32.47^{\mathrm{a}}$ & $31.44^{\mathrm{a}}$ & $26.02^{\mathrm{b}}$ & 2.77 & $* *$ \\
\hline
\end{tabular}

Means within row for each item having different superscript differ significantly $* *(\mathrm{p} \leq .01), * * *(\mathrm{p} \leq .001)$ 
Table (3): Effect of heat stress and grape seed extract supplementation on lipid peroxidation and some antioxidant enzymes in liver.

\begin{tabular}{|c|c|c|c|c|c|c|}
\hline & TN & $\begin{array}{c}\text { HSGSE } \\
0\end{array}$ & $\begin{array}{c}\text { HSGSE } \\
1\end{array}$ & $\begin{array}{c}\text { HSGSE } \\
2 \\
\end{array}$ & SEM & Significant \\
\hline $\begin{array}{l}\text { MDA }(\mathrm{nmol} / \mathrm{g} \\
\text { protein })\end{array}$ & $2.04^{c}$ & $3.93^{\mathrm{a}}$ & $3.22^{b}$ & $2.31^{\mathrm{c}}$ & 0.27 & $* * *$ \\
\hline $\begin{array}{ll}\mathrm{SOD} & (\mathrm{U} / \mathrm{mg} \\
\text { protein }) & \end{array}$ & $176.05^{\mathrm{a}}$ & $122.83^{c}$ & $159.18^{b}$ & $166.47^{\mathrm{ab}}$ & 5.47 & $* * *$ \\
\hline $\begin{array}{l}\mathrm{GSH}(\mu \mathrm{g} / \mathrm{mg} \\
\text { protein })\end{array}$ & $4.91^{\mathrm{a}}$ & $3.24^{\mathrm{c}}$ & $3.88^{\mathrm{b}}$ & $4.75^{\mathrm{a}}$ & 0.19 & $* * *$ \\
\hline
\end{tabular}

Means within row for each item having different superscript differ significantly $* * *(\mathrm{p} \leq .001)$

\section{REFERENCES}

Aengwanich, W.; and Suttajit, M. (2010). Effect of polyphenols extracted from tamarind (Tamarindus Indica L.) seed coat on physiological changes, heterophil/lymphocyte ratio, oxidative stress and body weight in broilers (Gallus domesticus) under chronic heat stress. Animal science journal, 81:264-270.

Akbari, M.; and Torki, M. (2013). Effects of dietary chromium picolinate and peppermint essential oil on growth performance and blood biochemical parameters of broiler chicks reared under heat stress conditions. Int $\mathbf{J}$ Biometeorol DOI 10.1007/s00484013-0740-1

Al-Ghamdi, Zahraa (2008). Effects of commutative heat stress on immunoresponses in broiler chickens reared in closed system. International Journal of Poultry Science 7, 964-968.

Ando, M.; Katagiri, K.; Yamamoto, S.; Wakamatsu, K.; Kawahara, I.; Asanuma, S.; Usuda, M.; and Sasaki, K. (1997). Age-related effects of heat stress on productive enzymes for peroxides and microsomal monooxygenase in rat liver. Environ Health Perspect 105:726-733

Attia, Y.A.; Hassan, R.A.; Tag El-Din, A.E.; and Abou-Shehema, B.M.(2010). Effect of ascorbic acid or increasing metabolizable energy level with or without supplementation of some essential amino acids on productive and physiological traits of slow-growing chicks exposed to chronic heat stress. Journal of Animal Physiology and Animal Nutrition 95 (2011) 744-755

Azad, M.A.; Kikusato, M.; Maekawa, T.; Shirakawa, H.; Toyomizu, M. (2010). Metabolic characteristics and oxidative damage to skeletal muscle in broiler chickens exposed to chronic heat stress. Comparative Biochemistry and Physiology. Part A, Molecular \& Integrative Physiology 155, 401-406.

Balu, M.; Sangeetha, P.; Haripriya, D.; and Panneerselvami, C. (2005). Rejuvenation of antioxidant system in central nervous system of aged rats by grape seed extract. Neurosci. Lett. 383, 295-300.

Benzie, I.F.F. (2003). Evolution of dietary antioxidants. Comparitive Biochemistyr and Physiology. Part A 136, 113-126. 
Boulahson, A.A.; Garlich, J.D.; Edens, F.W. (1995). Potassium chloride improve the thermotolerance of chickens exposed to acute heat stress. Poultry Science, 74, 75-87

Chen, L.; Haught, W.H.; Yang, B.; Saldeen, T.P.G.; Parathasarathy, S.; and Jawaher, L.M. (1997). Preservation of endogenous antioxidant activity and inhibition of lipid peroxidation as common mechanisms of antiatherosclerotic effects of vitamin E, lovastatin and amlodipine. J. Am. Coll Cardiol, 30:569-575.

Cooper, M.A.; Washburn, K.W. (1998). The relationships of body temperature to weight gain, feed consumption and feed utilization in broilers under heat stress. Poult Sci 77:237-242

Cos, P., De Bruyne, N.; Hermans, S.; Apers, D.; Berghe, V.; and Vlietink, A.J. (2003). Proanthocyanidins in health care current and new trends. Curr. Med. Chem. 10:1345-1359.

Devaraj, S.; and Jialal, I. (2000). Low density lipoprotein postsecretory modification, monocyte function, and circulating adhesion molecules in type 2 diabetic patients with and without macrovascular complications the effect of $\dot{\alpha}-$ tocopherol supplementation. Circulation 102:191-196.

Duncan, D.B. (1955). Multiple range and multiple F tests. Biometrics. 11:142.

Franchini, A.; Sirri, F.; Tallarico, N.; Minelli, G.; Iaffaldano, N.; and Meluzzi, A. (2002). Oxidative stability and sensory and functional properties of eggs from laying hens fed supranutritional doses of vitamins E and C. Poult. Sci. 81:1744-1750.
Grashorn, M.A. (2007). Functionality of poultry meat. J Appl Poult Res 16:99-106

Gross, W.B.; and Siegel, H.S. (1983). Evaluation of the heterophil/lymphocyte ratio as a measure of stress in chickens. Avian Disease. 27:972-978

Halliwell, B.E.; and Gutteridge, J.M.C. (1989). Lipid peroxidation: A radical chain reaction. Pages 188218 in Free Radicals in Biology and Medicine. 2nd ed. Oxford University Press, NewYork,NY.

Lin, H.; Jiao, H. C.; Buyse, J.; Decuypere, E. (2006). Strategies for preventing heat stress in poultry. World's Poultry Science Journal 62, 71-85.

Masaru, G.; Iwan, T.; Yukimi, K.; Kenshi M.; and Mitsutaka. K. (2004). Mechanical Evaluation of Effect of Grape Seed Proanthocyanidins Extract on Debilitated Mandibles in Rats. Dental Materials Journal 23(2): 6774.

McFarlane, G.M.; and Curtis, S.E. (1989). multiple concurrent stressors in chicks. 3-Effects on plasma corticosterone and the heterophil:lymphocyte ratio. Poultry Science. 68:522-527.

Mielnick, M.B.; Olsen, E.; Vogt, G.; Adeline, D.; and Skrede, G. (2006). Grape seed extract as antioxidant in cooked, cold stored turkey meat. LWT Food Science and Technology, 39, 191-198.

Mitsumoto, M.; O'Grady, M.N.; Kerry, J.P.; and Buckley, D.J. (2005). Addition of tea catechins and vitamin $\mathrm{C}$ on sensory evaluation, colour and lipid stability during chilled storage in cooked or raw beef and chicken patties. Meat Science, 69, 773-779. 
Mujahid, A.; Akiba, Y.; and Toyomizu, M. (2009). Olive oil-supplemented diet alleviates acute heat stressinduced mitochondrial ROS production in chicken skeletal muscle. Am J Physiol Regul Integr Comp Physiol 297:R690-R698

Mujahid, A.; Pumford, N.R.; Bottje, W.; Nakagawa, K.; Miyazawa, $\mathbf{T}$. Akiba, Y.; and Toyomizu, M. (2007). Mitochondrial oxidative damage in chicken skeletal muscle induced by acute heat stress. Jpn. Poult. Sci. 44:439-445.

Mujahid, A.; Yoshiki, Y.; and Akiba, Y. (2005). Superoxide radical production in chicken skeletal muscle induced by acute heat stress. Poult Sci 84:307-314

Murray, M.T. (1995). Grape seed extract and other sources of procyanidolic oligomers. In: The healing power of herbs. 2nd ed. Prima Publishing.

Nanari, M.C.; Hewavitharana, A.K.; Beca, C.; de Jong, S. (2004). Effect of dietary tocopherols and tocotrienols on the antioxidant status and lipid stability of chicken. Meat Sci 68:155-162

Nassir,F.; Moundras, C.; Bayle, D.; Serougne, C.; Gueux, E.; Rock, E.; Rayssiguier, Y.; and Mazur, A. (1997). Effect of selenium deficiency on hepatic lipid and lipoprotein metabolism in the rat. Br.J.Nutr., 78:493-500.

Ohkawa, H.; Ohishi, N.; and Yagi, K. (1979). Assay for lipid peroxides in animal tissues by thiobarbituric acid reaction. Anal. Biochem. 95: 351385.

Preuss, H.G.; Montamarry, S.; Echard, B.; Scheckenbach, R.; and Bagchi, D. (2001). Long-term of chromium, grape seed extract, and zinc on various metabolic parameters in rats. Mol. Cell. Biochem. 223:95-102.
Puthpongsiriporn, U.; Scheideler, S.E. ; Sell, J.L. ; and Beck, M.M. (2001). Effects of vitamin $\mathrm{E}$ and $\mathrm{C}$ supplementation on performance, in vitro lymphocyte proliferation, and antioxidant status of laying hens during heat stress. Poult. Sci. 80:1190-1200.

Rodrigo, R.; Castillo, R.; Carrasco, R.; Huerta, P.; and Moreno, $M$. (2005). Diminution of tissue lipid peroxidation in rats is related to the in vitro antioxidant capacity of wine. Life Sci. 76:889-900.

Sahin, K.; Orhan, C.; Tuzcu, M.; Ali, S.; Sahin, N.; and Hayirli, A. (2010). Epigallocatechin-3-gallate prevents lipid peroxidation and enhances antioxidant defense system via modulating hepatic nuclear transcription factors in heat-stressed quails. Poultry Science 89 :22512258

Sahin, K.; Sahin, N.; Kucuk, O.; Hayirli, A.; and Prasad, A.S. (2009). Role of dietary zinc in heat-stressed poultry: A review. Poult. Sci. 88:2176-2183.

Sahin, K.; Sahin, N.; Yaralioglu, S.; and Onderci, M. (2002). Protective role of supplemental vitamin $\mathrm{E}$ and selenium on lipid peroxidation, vitamin $\mathrm{E}$, vitamin $\mathrm{A}$, and some mineral concentrations of Japanese quails reared under heat stress. Biol. Trace Elem. Res. 85:59-70.

Sahin, N.; Akdemir, F.; Orhan, C.; Kucuk, O.; Hayirli, A.; and Sahin, K. (2008). Lycopene enriched quail egg as functional food for humans. Food Res. Int. 41:295-300.

Saito, M.; Hosoyama, H.; Ariga, T.; Kataoka, S.; and Yamaji, N. (1998). Antiulcer activity of grape seed extract and procyanidins. J. Agric. Food Chem. 46:1460-1464. 
Sandercock, D.A.; Hunter, R.R.; Nute, G.R.; Hocking, P.M.; Mitchell, M.A. (2001). Acute heat stressinduced alterations in blood acidbase status and skeletal muscle membrane integrity in broiler chickens at two ages: implications for meat quality. Poult Sci 80:418425

Sarkaki, A.; Rafieirad, M.; Hossini, S. E.; Farbood, Y.; Motamedi, F.; Mansouri, S.M.T.; Naghizadeh, B. (2013). Improvement in Memory and Brain Long-term Potentiation Deficits Due to Permanent Hypoperfusion/Ischemia by Grape Seed Extract in Rats. Iran J. Basic Med. Sci. 16: 1004-1010

SAS Institute (1988). SAS/STATUser's Guide. Release 6.03 Edition. SAS Institute, Inc., Cary, NC.

Schalm, D.W.; Jain, N.C.; and Caroll, E.J. (1975). Vetrinary Hematology. 3rd ed. Lea and Febiger, PA. USA.

Shi, J.; Yu, J.; Pohorly, E.; and Kakuda, Y. (2003). Polyphenolic in grape seeds- biochemistry and functionality. J. Med. Food 2003, 6, 291-299.

Shimada, K.; Watanabe, H.; Hosoda, K.; Takeuchi, K.; and Yoshikawa, J. (1999). Effect of red wine on coronary flow-velocity reserve. Lancet. 254:1002.

Simons, S.S.; and Johnson, D.F. (1978). Reaction of o-phtal-alaldehyde and thiols with primary amines: Fluoroscence properties of 1-alkyl (and aryl) thio-2-alkylisoindoles. Anal Biochem 1978;90:705-25.

Singh, R.P.; Tuagi, A.K.; Dhanalakshmi, S.; Agarwal, R.; and Agarwal, C. (2004). Grape seed extract inhibits advanced human prostate tumor growth and angiogenesis and upregulates insulin-like growth factor binding protein-3. Int. J. Cancer. 108, 733-740.
Star, L.; Kemp, B.; Van den Anker, I.; and Parmentier, H.K. (2008). Effect of single and combined climatic and hygienic stress in four layer lines. 1- Performance. Poultry Science, 87:1022-1030.

Strain, J.J.; Benzie, I.F.F. (1999). Diet and antioxidant defence. In: M. J. Sadler, J. J. Strain, B. Caballero (eds), Encyclopedia of Human Nutrition. Academic Press, London, pp. 95-106.

Tan, G.Y.; Yang, L.; Fu, Y.Q.; Feng, J. H.; and Zhang, M. H. (2010). Effects of different acute high ambient temperatures on function of hepatic mitochondrial respiration, antioxidative enzymes, and oxidative injury in broiler chickens. Poult. Sci. 89:115-122.

Teissedre, P.L.; and Waterhouse, A.L. (2000). Inhibition of oxidation of human low-density lipoproteins by phenolic substances in different essential oils varieties. J Agric Food Chem 48:3801-3805

Tuzcu, M.; Sahin, N.; Karatepe, M.; Cikim, G.; Kilinc, U.; and Sahin, K. (2008). Epigallocatechin-3gallate supplementation can improve antioxidant status in stressed quail. Br. Poult. Sci. 49:643-648.

Wang, R.R.; and Pan XJ, Peng, Z.Q. (2009). Effects of heat exposure on muscle oxidation and protein functionalities of pectoralis majors in broiler. Poult Sci 88:1078-1084

Willemsen, H.; Swennen, Q.; Everaert, N.; Geraert, P.A; Mercier, Y.; Stinckens, A.; Decuypere, E.; and Buyse, J. (2011). Effects of dietary supplementation of methionine and its hydroxyl analog DL-2-hydroxy4-methylthiobutanoic acid on growth performance, plasma hormone levels and the redox status of broiler chickens exposed to high 
temberatures. Poultry Science, Yamakoshi, J.; Kataoka, S.; Koga, T.; 90:2311-2320 and Ariga, T. (1999).

Worthington, V. (1993). Superoxide Dismutase. Pages 368-369 - in Worthington Enzyme Manual. N.J.Freehold, ed. Worthington Biochemical Corp., Lakewood, NJ

Yalçın, S.; Ozkan, S.; Cabuk M.C.; and. Siegel, P.B. (2003). Criteria for evaluating husbandry practices to alleviate heat stress in broilers. J. Appl. Poult. Res. 12:382-388.

Proanthocyanidin-rich extract from grape seeds attenuates the development of aortic atherosclerosis in cholesterol-fed rabbits. Atherosclerosis 142:139149.

Yilmaz, Y.; and Toledo, R.T. (2004). Major flavonoids in grape seed and skins: Antioxidant capacity of catechin, epicatechin and gallic acid. Journal of Agricultural and Food Chemistry, 52, 255-260.

\title{
الملخص العربي
}

\section{تأثير مستخلص بذر العنب على التغييرات الفسيولوجية لاجاج التسمين المعرض للاجهاد الحرارى}

\author{
سعد ز غلول محمد الدمر اوى \\ قسم الانتاج الحيو انى - كلية الزر اعة - جامعة طنطا- مصر.
}

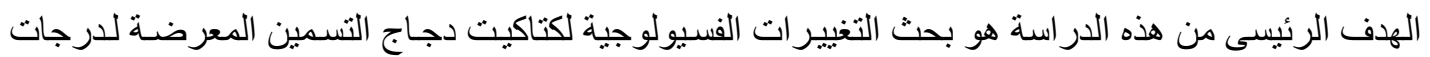

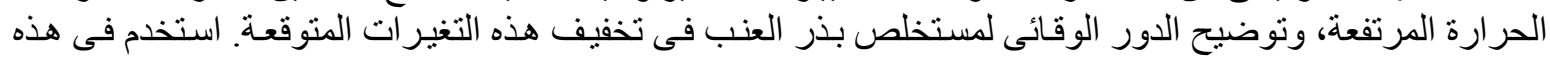

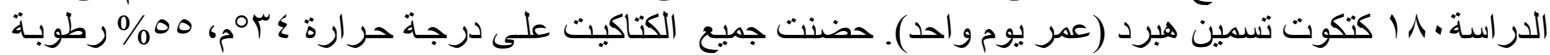

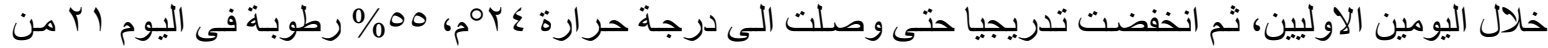

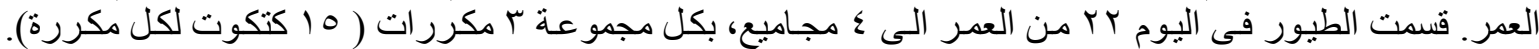

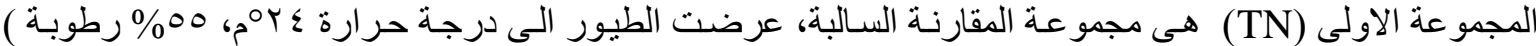

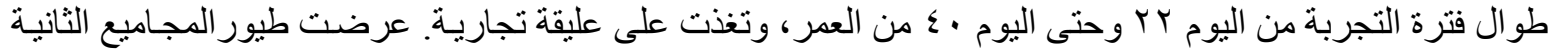

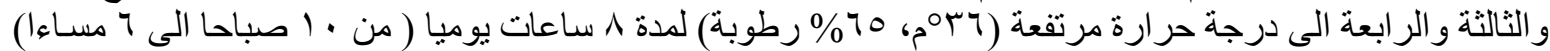

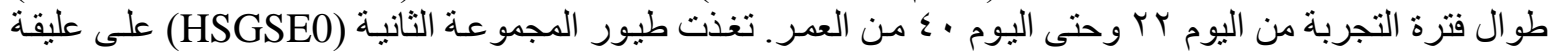

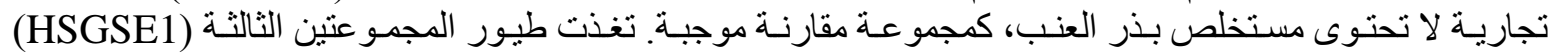

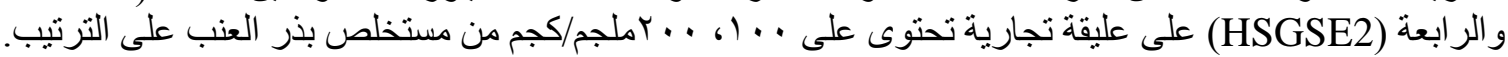

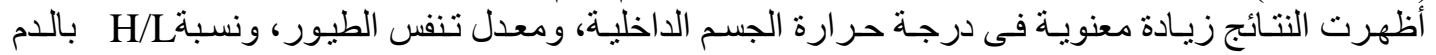

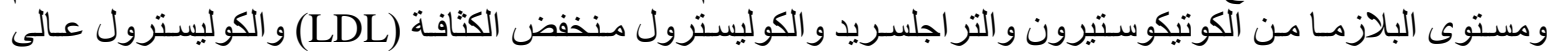

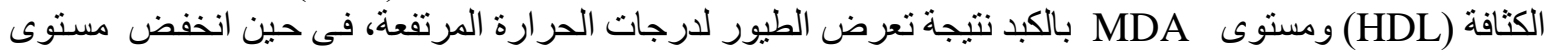

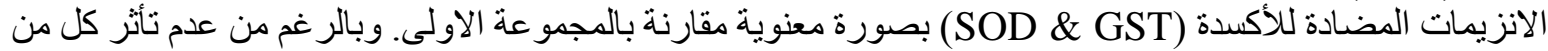

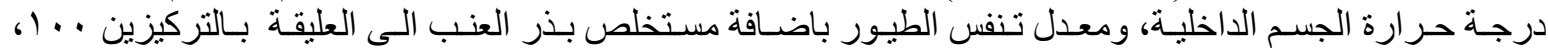

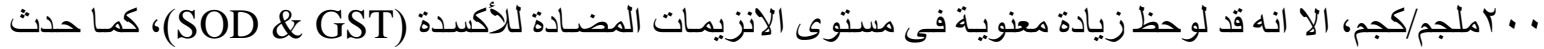

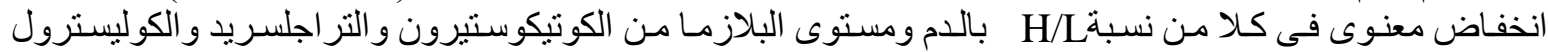

منخفض الكثافة (LDL) و الكوليسترول عالى الكثافة (HDL) ومستوى MDA بالكبد مقارنة بالمجمو عة الثانية.

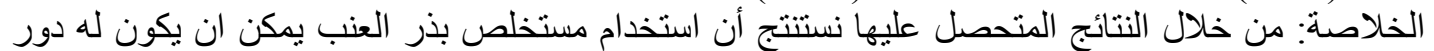

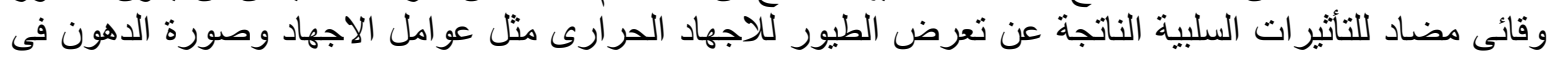

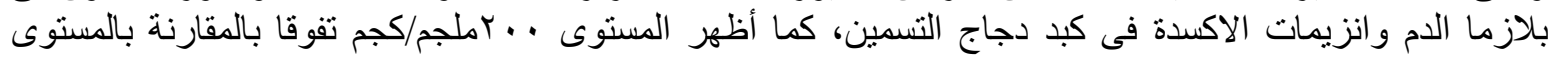

